\title{
Prediction of Outcome of 100 Acute Stroke Patients in a Tertiary Level Hospital
}

\author{
${ }^{1}$ Dr. Md. Emdadul Haque, ${ }^{2}$ Dr. Md. Tofael Hossain Bhuiyan, ${ }^{3}$ Dr. Khandoker \\ Ataur Rahman, ${ }^{4}$ Dr. Sukumar Majumder, ${ }^{5}$ Dr. Proshanta Kumar Pondit \\ ${ }^{I}$ Assistant Professor, Dept. of Neurology, Rangpur Medical College, Bangladesh \\ ${ }^{2}$ Associate Professor, Dept. of Neurosurgery, Rangpur Medical College, Bangladesh \\ ${ }^{3}$ Registrar, Department of Neurology, Rangpur Medical College Hospital, Bangladesh \\ ${ }^{4}$ Assistant Professor, Department of Neurology, Rangpur Medical college, Bangladesh \\ ${ }^{5}$ Jr. Consultant (Medicine), Department of Medicine, Rangpur Medical College Hospital, Bangladesh
}

\begin{abstract}
:
Physicians are often facing the task of predicting the immediate and long-term outcome in stroke patients. Early predictor of mortality and poor outcome are crucial for planning the level of care and optimizing resource utilization. It is important efficiently and optimally to utilize resources. The use of early prognostic data provided by various scores in critically ill stroke patients remains unclear. The objective of the study was to determine validity of GCS for prediction of short-term mortality in acute stroke patients. Purposive sampling method was applied for the study. The patients who have fulfilled both inclusion and exclusion criteria, were enrolled in this study. The samples were collected by the investigator himself. Total GCS were labeled into three groups $(I, I I, I I I)$. Prognosis of patients of 3 groups was tested by chi square $\left(x^{2}\right)$ test. Overall 7-day and 28-day case fatality was $42 \%$ and $52 \%$ respectively. On the basis of CT scan finding, one-week case fatality of ICH and CI was $44.8 \%$ and $36.4 \%$ respectively. Four-week case fatality of ICH and CI was $56.7 \%$ and $42.4 \%$ respectively. One-week case fatality of 3 groups (I, II, III) was $84.6 \%, 24.1 \%$ and $6.3 \%$ respectively. Four-week case fatality of 3 groups was $89.7 \%, 44.8 \%$ and $12.5 \%$ respectively. In chi square $\left(x^{2}\right)$ test, the difference in mortality of 3 groups of was statistically significant $(P<0.05)$ at one week and four weeks follow up. This study shows, GCS is a valuable tool for prediction of short-term mortality in acute stroke patients. The less the GCS score at the onset of acute stroke the more is mortality.
\end{abstract}

Keywords: GCS, Prognosis, CT scan, ICH and CI, Stroke, Mortality

\section{Introduction}

Stroke is the third most common cause of death in the developed world after ischaemic heart disease and cancer at all sites. ${ }^{[1]}$ In the United States there are approximately 7,00000 cases of stroke each year- roughly 6,00000 infarction and 1,00000 hemorrhages with 1,75,000 fatalities from these causes. ${ }^{[2]}$ It accounts for $12 \%$ of all deaths in England and Wales and is the most common cause of severe disability in people living in their own home. Strokes account for 5.54 million deaths worldwide ${ }^{[4]}$ being the second commonest cause of mortality. Other data suggest that two-thirds of these deaths occur in less developed countries. In many developing countries the incidence is rising because of the adoption of less healthy life styles. Out of 1434 patients admitted in Neuro-medicine unit of Rajshahi Medical College Hospital in 2006, 1,119 were suffering from stroke (Department register). About one-fifth of patients with an acute stroke will die within a month of the event and at least half of those who survive will be left with physical disability(Allen et al, 2006).

Table-1: Tabulated form of GCS

\begin{tabular}{|c|c|c|c|c|c|c|}
\hline $\begin{array}{l}\text { Components of } \\
\text { GCS }\end{array}$ & 6 & 5 & 4 & 3 & 2 & 1 \\
\hline Eyes opening & N/A & N/A & $\begin{array}{l}\text { Opens eyes } \\
\text { spontaneously }\end{array}$ & $\begin{array}{ll}\text { Opens eyes } & \text { in } \\
\text { response } & \text { to } \\
\text { voice } & \\
\end{array}$ & $\begin{array}{l}\text { Opens eyes } \\
\text { to painful } \\
\text { stimuli }\end{array}$ & $\begin{array}{l}\text { Does not } \\
\text { open eyes }\end{array}$ \\
\hline Verbal response & N/A & $\begin{array}{l}\text { Oriented, } \\
\text { converses } \\
\text { normally } \\
\end{array}$ & $\begin{array}{l}\text { Confused, } \\
\text { disoriented }\end{array}$ & $\begin{array}{l}\text { Utters } \\
\text { inappropriate } \\
\text { words }\end{array}$ & $\begin{array}{l}\text { Incompre- } \\
\text { hensible } \\
\text { sounds }\end{array}$ & $\begin{array}{l}\text { Makes no } \\
\text { sounds }\end{array}$ \\
\hline $\begin{array}{ll}\text { Best } & \text { motor } \\
\text { response } & \end{array}$ & $\begin{array}{l}\text { Obeys } \\
\text { commands }\end{array}$ & $\begin{array}{l}\text { Localizes } \\
\text { painful } \\
\text { stimuli }\end{array}$ & $\begin{array}{l}\text { Withdraws } \\
\text { from painful } \\
\text { stimuli }\end{array}$ & $\begin{array}{l}\text { Flexor } \\
\text { posturing upon } \\
\text { painful stimuli }\end{array}$ & $\begin{array}{l}\text { Extensor } \\
\text { posturing } \\
\text { upon } \\
\text { painful } \\
\text { stimuli }\end{array}$ & $\begin{array}{l}\text { Makes no } \\
\text { movements }\end{array}$ \\
\hline
\end{tabular}

Generally, Comas are classified as (Chao et al 2009): 


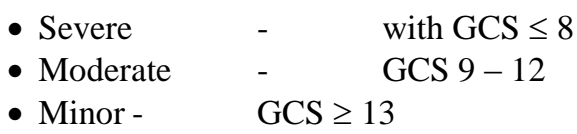

As stroke may cause localized motor, speech or language deficits, the accuracy of GCS as a measure of consciousness level may be affected. In turn it's prognostic value may be impaired. Conversely, in-patient with a language disorder, the verbal score may reflect stroke severity in addition to its measurement of consciousness level and for that reason it may retain useful prognostic information.

Hypothesis:

GCS level at the onset of acute stroke is a valid predictor of short-term mortality in stroke patients.

\section{Objective}

\section{General objective:}

To determine validity of GCS for prediction of short-term mortality in acute stroke patients.

\section{Specific objectives:}

- To determine the GCS level at the onset of acute stroke.

- To measure the mortality of acute stroke patients within 7 days and 28 days of stroke onset.

- To compare the short-term mortality between admitted hemorrhagic and ischaemic stroke patients.

\section{Study type:}

\section{Methodology}

Observational-descriptive study.

Study time:

01 year and 04 months. It includes article reviews, development of thesis protocol, data collection, data analysis and paper writing.

\section{Study place:}

1. Department of Neuro-medicine, Rajshahi Medical College Hospital, Rajshahi.

2. Department of Medicine, Rajshahi Medical College Hospital, Rajshahi.

3. Neuroimaging was done in Radiology department of Rajshahi Medical College Hospital, Rajshahi.

\section{Patients:}

Both hemorrhagic (ICH) and Ischaemic stroke patients were taken who were admitted with in 24 hours of stroke onset.
a) 7.5. Sample size: 100

\section{Inclusion criteria:}
1. Haemorrhagic stroke.
2. Ischaemic stroke.
3. Admitted within 24 hours of stroke onset.
4. Age between $20-80$ years.
5. Both male and female were enrolled.

\section{Exclusion criteria:}

1. Admitted after 24 hours of stroke onset.

2. Age below 20 years and above 80 years.

3. Transient ischemic attack.

4. Primary subarachnoid hemorrhage.

5. Patients with associated debility and co morbidity e.g. myocardial infarction, atrial fibrillation, cancer etc.

6. CT scans of brain other than stroke like tumor, abscess, sub-dural hematoma etc.

\section{Sample procedure:}

Purposive sampling method.

\section{Sample collection:}

The patients who have fulfilled both inclusion and exclusion criteria, were enrolled in this study. The samples were collected by the investigator himself.

DOI: 10.9790/0853-1605081725 $\quad$ www.iosrjournals.org $\quad 18 \mid$ Page




\section{Procedure/Data collection:}

Data was collected with the help of a structured questionnaire and face-to-face interview with the patients (where possible) or attendants of the patient. Complete history, physical examination including GCS were done and recorded in a case record form by the investigator himself. On admission relevant data about past medical history, vascular risk factors and associated conditions were obtained from patients, families, caregivers or prior medical records following the definitions recommended by the international guidelines (Ois et al 2007) as follows: age, sex, hypertension (evidence of at least 2 raised blood pressure measurements, systolic $>140 \mathrm{~mm}$ of $\mathrm{Hg}$ or diastolic $>90 \mathrm{~mm} \mathrm{Hg}$ on different days before stroke onset, Physician diagnosis or use of medication), diabetes (a physician diagnosis or use of diabetes medication), tobacco use, alcohol abuse, presence of heart disease (documented history of angina pectoris or myocardial infarction, electrocardiographic or clinical diagnosis), history of previous stroke, family history of stroke, use of oral contraceptives.

CT scan of brain was done of each patient to confirm the diagnosis.

\section{The patients were grouped into three -}

$\begin{array}{cc}\text { Group A: } & \text { GCS, 3-8 } \\ \text { Group B : } & \text { GCS ,9-12 } \\ \text { Group C : } & \text { GCS , 13-15 }\end{array}$

The follow up of the patients was done by the investigator himself on 7th and 28th day of stroke onset. Death records of one week were collected from the death register of the wards. Rest of the patients had been discharged before 28th day; so death records were collected in follow up visits/ over telephone from the attendants of the patients.

\section{Data analysis:}

\section{Descriptive data-}

Data of the patients were compared and correlated to see the short-term mortality of three GCS groups, both haemorrhagic and ischaemic stroke.

\section{Statistical analysis:}

Data was analyzed with the help of SPSS soft ware programme and expressed as Mean +/-SD. P-value $<0.05$ was considered significant. Bibliography is written in Harvard style.

\section{Research instruments:}

A checklist was prepared by the researcher himself considering the variables such as age of the patients, sex of the patients, history of smoking, history of alcoholism, family history of stroke, heart diseases, admission level blood pressure (both SBP \& DBP), Glasgow coma scale at the onset of stroke, CT scan findings.

\section{Investigations:}

CT scan was done in all patients. Other investigations like blood sugar, S.creatinine, ECG \& S. electrolyte were also done.

\section{Ethical issues:}

Eligibility of each case was assessed and identified and every patient and/or responsible family member had been asked for informed consent. They were informed about the procedure and study goal. The eligible patient and/or family member were informed that there were no extra costs to the patients for the investigations.

\section{Age distribution of patients:}

\section{Results}

In the study, the patients were divided into five age groups. The age ranged from 38 to 80 years and the maximum number of patients was found in the age group of 51-60 years. The mean age was 59.3 years with standard deviation (SD) \pm 10.4 years. The distribution of mean age of 100 patients was shown in table 2 .

Table 2: Age distribution of the patients $(n=100)$

\begin{tabular}{|l|l|l|}
\hline Age in year & No of patients & Percentage \\
\hline$\leq 40$ & 7 & 7.0 \\
\hline $41-50$ & 15 & 15.0 \\
\hline $51-60$ & 39 & 39.0 \\
\hline
\end{tabular}




\begin{tabular}{|l|l|l|}
\hline $61-70$ & 29 & 29.0 \\
\hline $71-80$ & 10 & 10.0 \\
\hline Total & 100 & 100.0 \\
\hline mean \pm SD & 59.3 & \pm 10.4 \\
Range (Min-max) & 38 & -80 \\
\hline
\end{tabular}

\section{Sex distribution of the study patients $(\mathrm{n}=100)$ :}

This study was carried out in 100 patients of whom $61.0 \%$ were male and rest $39.0 \%$ were female patients. The results are shown in the table 3 .

Table 3: Sex distribution of the patients $(\mathrm{n}=100)$

\begin{tabular}{|l|l|l|}
\hline Sex & No of patients & Percentage \\
\hline Male & 61 & 61.0 \\
\hline Female & 39 & 39.0 \\
\hline Total & 100 & 100.0 \\
\hline
\end{tabular}

\section{Risk factors of the study patients $(n=100)$ :}

Majority of the patients (70.0\%) were hypertensive, $40.0 \%$ were smoker, $21.0 \%$ had history of previous stroke, $20.0 \%$ had family history of stroke, $14.0 \%$ had DM, $17.0 \%$ had heart disease and $2.0 \%$ were alcoholic. The results are shown in the figure 1.

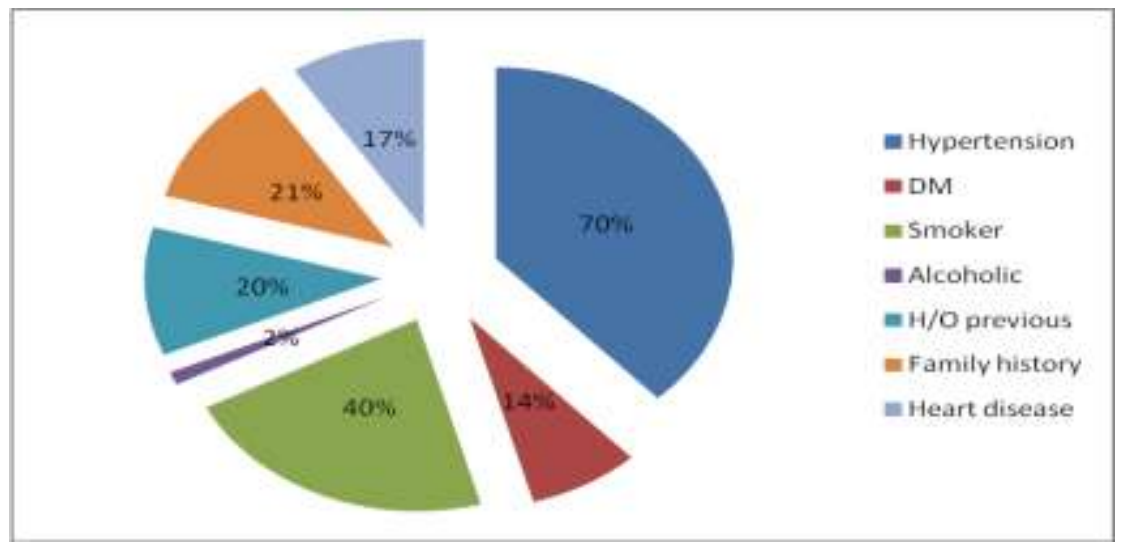

Figure 1: Pie chart showing the main vascular risk factors of the patients

Blood pressure of the study patients $(n=100)$ :

The patient's were divided into three groups according to their GCS score: $\leq 8$ considered as severe group (group I); 9-12 considered as moderate group (group II); and $\geq 13$ considered as Minor GCS group (group III). Systolic blood pressure varied from 100 to $280 \mathrm{mmHg}$ and the mean $\pm \mathrm{SD}$ was $174.9 \pm 53.5 \mathrm{mmHg}$ in group I, in group II mean \pm SD was $166.4 \pm 33.2 \mathrm{mmHg}$ and varied from 120 to $245 \mathrm{mmHg}$ and in group III mean $\pm \mathrm{SD}$ was $158.5 \pm 33.9 \mathrm{mmHg}$ and varied from 110 to $224 \mathrm{mmHg}$. Diastolic blood pressure varied from 60 to 140 $\mathrm{mmHg}$ and the mean $\pm \mathrm{SD}$ was $97.7 \pm 23.4 \mathrm{mmHg}$ in group I, in group II mean $\pm \mathrm{SD}$ was $98.8 \pm 13.7 \mathrm{mmHg}$ varied from 70 to $135 \mathrm{mmHg}$ and in group III mean \pm SD was $85.5 \pm 17.1 \mathrm{mmHg}$ varied from 65 to $130 \mathrm{mmHg}$. Systolic blood pressures were not statistically significantly different $(\mathrm{p}>0.05)$ but diastolic blood pressures were statistically significantly different $(\mathrm{p}<0.05)$ in ANOVA test. The results are shown in the table 4 .

Table 4: Mean blood pressure of the study patients $(n=100)$

\begin{tabular}{|c|c|c|c|c|}
\hline $\begin{array}{l}\text { Blood pressure } \\
(\mathrm{mmHg})\end{array}$ & $\begin{array}{l}\text { Group I } \\
(\mathrm{n}=39)\end{array}$ & $\begin{array}{l}\text { Group II } \\
(\mathrm{n}=29)\end{array}$ & $\begin{array}{l}\text { Group III } \\
(n=32)\end{array}$ & $\begin{array}{l}\mathrm{P} \\
\text { value }\end{array}$ \\
\hline & Mean \pm SD & Mean \pm SD & Mean \pm SD & \multirow[t]{3}{*}{$0.282 \mathrm{NS}$} \\
\hline Systolic BP & $174.9 \pm 53.5$ & $166.4 \pm 33.2$ & $158.5 \pm 33.9$ & \\
\hline Range & $(100-280)$ & $(120-245)$ & $(110-224)$ & \\
\hline Diastolic BP & $97.7 \pm 23.4$ & $98.8 \pm 13.7$ & $85.5 \pm 17.1$ & \multirow[t]{2}{*}{$0.011 \mathrm{~S}$} \\
\hline Range & $(60-140)$ & $(70-135)$ & $(65-130)$ & \\
\hline
\end{tabular}

$*$ Group I= $\leq 8$ GCS score 
*Group II=9-12 GCS score

*Group III= $\geq 13$ GCS score

$* \mathrm{NS}=$ not significant, $* \mathrm{~S}=$ Significant

$* \mathrm{P}$ value reached from ANOVA test

\section{CT scan of brain of the study patients $(n=100)$ :}

The patient's were divided into three groups according to their GCS score: $\leq 8$ consider as severe group (group I); 9-12 considers as moderate group (group II); and $\geq 13$ consider as Minor GCS group (group III). CT scan was done for all 100 cases and it was observed that hemorrhage was found in $28(71.8 \%)$ in group I, $22(75.9 \%)$ in group II and $17(53.1 \%)$ in group III. Infarcts were $11(28.2 \%)$ in group I, $7(24.1 \%)$ in group II and $15(46.9 \%)$ in group III. The results are shown in the table 5.

Table 5: Distribution of the patients according to CT scan diagnosis of brain ( $\mathrm{n}=100)$

\begin{tabular}{|l|l|l|l|l|l|l|}
\hline \multirow{2}{*}{ CT scan of brain } & \multicolumn{2}{|l|}{$\begin{array}{l}\text { Group I } \\
(\mathrm{n}=39)\end{array}$} & \multicolumn{2}{l|}{$\begin{array}{l}\text { Group II } \\
(\mathrm{n}=29)\end{array}$} & $\begin{array}{l}\text { Group III } \\
(\mathrm{n}=32)\end{array}$ \\
\cline { 2 - 8 } & $\mathrm{n}$ & $\%$ & $\mathrm{n}$ & $\%$ & $\mathrm{n}$ & $\%$ \\
\hline Hemorrhage & 28 & 71.8 & 22 & 75.9 & 17 & 53.1 \\
\hline Infarct & 11 & 28.2 & 7 & 24.1 & 15 & 46.9 \\
\hline
\end{tabular}

*Group I= $\leq 8$ GCS score

*Group II=9-12 GCS score

*Group III= $\geq 13$ GCS score

Blood sugar of the study patients $(n=100)$ :

Blood sugar test was done for all 100 cases and it was observed that blood sugar varied from 99 to $284.4 \mathrm{mg} / \mathrm{dl}$ and the mean \pm SD was $167.1 \pm 62.7 \mathrm{mg} / \mathrm{dl}$ in group I, in group II mean $\pm \mathrm{SD}$ was $152.5 \pm 59.3 \mathrm{mg} / \mathrm{dl}$ varied from 99 to $277.2 \mathrm{mg} / \mathrm{dl}$ and in group III mean \pm SD was $130.7 \pm 47.0 \mathrm{mg} / \mathrm{dl}$ varied from 110.1 to $208.8 \mathrm{mg} / \mathrm{dl}$. The higher blood sugars the lower the GCS. The difference was statistically significant $(\mathrm{p}<0.05)$ among the groups in ANOVA test. The results are shown in the table 6.

Table 6: Mean blood sugar of the study patients $(n=100)$

\begin{tabular}{|c|c|c|c|c|c|c|c|}
\hline Blood sugar $(\mathrm{mg} / \mathrm{dl})$ & \multicolumn{2}{|c|}{$\begin{array}{l}\text { Group I } \\
(\mathrm{n}=39)\end{array}$} & \multicolumn{2}{|c|}{$\begin{array}{l}\text { Group II } \\
(\mathrm{n}=29)\end{array}$} & \multicolumn{2}{|c|}{$\begin{array}{l}\text { Group III } \\
(\mathrm{n}=32)\end{array}$} & $\begin{array}{l}\mathrm{P} \\
\text { value } \\
\end{array}$ \\
\hline Mean \pm SD & 167.1 & \pm 62.7 & 152.5 & \pm 59.3 & 130.7 & \pm 47.0 & $0.023 \mathrm{~S}$ \\
\hline Range & (99.0 & $-284.4)$ & $(99.0$ & $-277.2)$ & (110.1 & $-208.8)$ & \\
\hline
\end{tabular}

*Group I $=\leq 8$ GCS score

*Group II=9-12 GCS score

*Group III= $\geq 13$ GCS score

$* \mathrm{~S}=$ significant

$* \mathrm{P}$ value reached from ANOVA test

\section{ECG finding of the study patients $(n=51)$ :}

ECG was done for 51 cases and it was observed that LVH were found in 14(63.6\%) in group I,

$7(70.0 \%)$ in group II and $10(52.6 \%)$ in group III. Normal were in $8(37.4 \%)$ in group I, 3(30.0\%) in group II and $9(47.4 \%)$ in group III. No statistically significant $(\mathrm{p}>0.05)$ difference was found among the groups in chi square test. The results are shown in the table 7.

Table 7: ECG finding of the study patients $(n=51)$

\begin{tabular}{|l|l|l|l|l|l|l|l|}
\hline \multirow{2}{*}{ ECG } & \multicolumn{2}{|l|}{$\begin{array}{l}\text { Group I } \\
(\mathrm{n}=22)\end{array}$} & \multicolumn{2}{l|}{$\begin{array}{l}\text { Group II } \\
(\mathrm{n}=10)\end{array}$} & \multicolumn{2}{l|}{$\begin{array}{l}\text { Group III } \\
(\mathrm{n}=19)\end{array}$} & $\begin{array}{l}\text { P } \\
\text { value }\end{array}$ \\
\cline { 2 - 8 } & $\mathrm{n}$ & $\%$ & $\mathrm{n}$ & $\%$ & $\mathrm{n}$ & $\%$ & \\
\cline { 1 - 7 } LVH & 8 & 36.36 & 3 & 30.0 & 6 & 31.57 & \multirow{2}{*}{0.618} \\
\cline { 1 - 7 } NAD & 14 & 63.63 & 7 & 70.0 & 13 & 68.42 & NS \\
\hline
\end{tabular}

*Group I= $\leq 8$ GCS score

*Group II=9-12 GCS score

*Group III= $\geq 13$ GCS score

$* \mathrm{NS}=$ not significant

*P value reached from chi square test 
Serum creatinine of the study patients $(n=100)$ :

Serum creatinine investigation was done for all 100 cases. The difference was not statistically significant ( $>0.05$ ) among the groups in ANOVA test. The results are shown in the table 7.

Table 7: Serum creatinine of the study patients $(\mathrm{n}=100)$

\begin{tabular}{|c|c|c|c|c|c|c|c|}
\hline S. Creatinine $(\mathrm{mg} / \mathrm{dl})$ & \multicolumn{2}{|c|}{$\begin{array}{l}\text { Group I } \\
(\mathrm{n}=39)\end{array}$} & \multicolumn{2}{|c|}{$\begin{array}{l}\text { Group II } \\
(\mathrm{n}=29)\end{array}$} & \multicolumn{2}{|c|}{$\begin{array}{l}\text { Group III } \\
(\mathrm{n}=32)\end{array}$} & $\begin{array}{l}\mathrm{P} \\
\text { value }\end{array}$ \\
\hline Mean \pm SD & 1.2 & \pm 0.2 & 1.2 & \pm 0.1 & 1.3 & \pm 0.2 & $0.624 \mathrm{NS}$ \\
\hline Range & $(0.79$ & $-1.6)$ & $(1.1$ & $-1.5)$ & $(1.0$ & $-2.0)$ & \\
\hline
\end{tabular}

*Group $\mathrm{I}=\leq 8$ GCS score

*Group II=9-12 GCS score

*Group III $=\geq 13$ GCS score

$* \mathrm{NS}=$ not significant

$* \mathrm{P}$ value reached from ANOVA test

Outcome of the total patients at one week follow-up $(n=100)$ :

It was observed that $33(84.6 \%)$ patients died at one week follow-up in group I, $7(24.1 \%)$ in group II and $2(6.3 \%)$ in group III. The difference was statistically significant $(\mathrm{p}<0.05)$ among the groups in Chi square test. The results are shown in the table 8 .

Table 8: Outcome of the patients at one-week follow-up $(n=100)$

\begin{tabular}{|l|l|l|l|l|l|l|l|}
\hline \multirow{2}{*}{ At one week } & \multicolumn{2}{|l|}{$\begin{array}{l}\text { Group I } \\
(\mathrm{n}=39)\end{array}$} & \multicolumn{2}{l|}{$\begin{array}{l}\text { Group II } \\
(\mathrm{n}=29)\end{array}$} & \multicolumn{2}{l|}{$\begin{array}{l}\text { Group III } \\
(\mathrm{n}=32)\end{array}$} & $\begin{array}{l}\text { P } \\
\text { value }\end{array}$ \\
\cline { 2 - 7 } & $\mathrm{n}$ & $\%$ & $\mathrm{n}$ & $\%$ & $\mathrm{n}$ & $\%$ & \\
\cline { 1 - 7 } Patient is alive & 6 & 15.4 & 22 & 75.9 & 30 & 93.8 & \multirow{2}{*}{$0.001 \mathrm{~S}$} \\
\hline Death & 33 & 84.6 & 7 & 24.1 & 2 & 6.3 & \\
\hline
\end{tabular}

*Group I= $\leq 8$ GCS score

*Group II=9-12 GCS score

*Group III= $\geq 13$ GCS score

$* \mathrm{~S}=$ significant

*P value reached from Chi square test

Outcome of the patients at four week follow-up $(n=58)$.

It was observed that 2(33.3\%) patients died at four-week follow-up in group I, 6(27.3\%) in group II and 2(6.7\%) in group III. The difference was not statistically significant ( $>>0.05)$ among the groups in Chi square test. The results are shown in the table 9.

Table 9: Outcome of the patients at four-week follow-up $(n=58)$.

\begin{tabular}{|l|l|l|l|l|l|l|l|}
\hline \multirow{2}{*}{ At four weeks } & \multicolumn{2}{|l|}{$\begin{array}{l}\text { Group I } \\
(\mathrm{n}=6)\end{array}$} & \multicolumn{2}{l|}{$\begin{array}{l}\text { Group II } \\
(\mathrm{n}=22)\end{array}$} & \multicolumn{2}{l|}{$\begin{array}{l}\text { Group III } \\
(\mathrm{n}=30)\end{array}$} & $\begin{array}{l}\text { P } \\
\text { value }\end{array}$ \\
\cline { 2 - 8 } & $\mathrm{n}$ & $\%$ & $\mathrm{n}$ & $\%$ & $\mathrm{n}$ & $\%$ & \\
\hline Patient is alive & 4 & 66.7 & 16 & 72.7 & 28 & 93.3 & \multirow{2}{*}{0.567 NS } \\
\hline Death & 2 & 33.3 & 6 & 27.3 & 2 & 6.7 & \\
\hline
\end{tabular}

$*$ Group I $=\leq 8$ GCS score

*Group II=9-12 GCS score

*Group III= $\geq 13$ GCS score

$* \mathrm{NS}=$ not significant

*P value reached from chi square test

Outcome of the total patients at four week follow-up $(n=100)$ :

It was observed that $35(89.7 \%$ ) patients died at four week follow-up in group I,13(44.8\%) in group II and $4(12.5 \%)$ in group III. The difference was statistically significant $(\mathrm{p}<0.05)$ among the groups in Chi square test. The results are shown in the table 10 . 
Table 10: Outcome of the total patients at four-week follow-up ( $\mathrm{n}=100)$.

\begin{tabular}{|l|l|l|l|l|l|l|l|}
\hline At four weeks & \multicolumn{2}{|l|}{$\begin{array}{l}\text { Group I } \\
(\mathrm{n}=39)\end{array}$} & \multicolumn{2}{l|}{$\begin{array}{l}\text { Group II } \\
(\mathrm{n}=29)\end{array}$} & \multicolumn{3}{l|}{$\begin{array}{l}\text { Group III } \\
(\mathrm{n}=32)\end{array}$} \\
\cline { 2 - 8 } & $\mathrm{n}$ & $\%$ & $\mathrm{n}$ & $\%$ & $\mathrm{n}$ & $\%$ & \\
\hline Patient is alive & 4 & 10.3 & 16 & 55.2 & 28 & 87.5 & \multirow{2}{*}{$0.001 \mathrm{~S}$} \\
\hline Death & 35 & 89.7 & 13 & 44.8 & 4 & 12.5 & \\
\hline
\end{tabular}

*Group I= $\leq 8$ GCS score

*Group II=9-12 GCS score

*Group III $=\geq 13$ GCS score

$* \mathrm{~S}=$ Significant

*P value reached from chi square test

Outcome of the patients at one-week follow-up according to their CT scan findings $(\mathbf{n}=100)$ :

It was observed that 37(55.2\%) hemorrhage and 21(63.6\%) infarct patients were alive at one-week follow-up. The results are shown in the table 11 .

Table 11: Outcome of the patients at one-week follow-up according to their CT scan findings $(n=100)$

\begin{tabular}{|l|l|l|l|l|}
\hline At one week & \multicolumn{2}{|l|}{$\begin{array}{l}\text { Hemorrhage } \\
(\mathrm{n}=67)\end{array}$} & $\begin{array}{l}\text { Infarct } \\
(\mathrm{n}=33)\end{array}$ \\
\hline & $\mathrm{n}$ & $\%$ & $\mathrm{n}$ & $\%$ \\
\hline Patient is alive & 37 & 55.2 & 21 & 63.6 \\
\hline Death & 30 & 44.8 & 12 & 36.4 \\
\hline
\end{tabular}

Outcome of the patients at four-week follow-up according to their CT scan findings $(\mathbf{n}=\mathbf{5 8})$ :

During four-week follow-up it was observed that 29(78.4\%) hemorrhage and 19(90.5\%) infarct patients were alive. The results are shown in the table 12.

Table 12: Outcome of the patients at four-week follow-up according to their CT scan findings $(n=58)$

\begin{tabular}{|l|l|l|l|l|}
\hline At four week & \multicolumn{2}{|l|}{$\begin{array}{l}\text { Hemorrhage } \\
(\mathrm{n}=37)\end{array}$} & \multicolumn{2}{l|}{$\begin{array}{l}\text { Infarct } \\
(\mathrm{n}=21)\end{array}$} \\
\hline & $\mathrm{n}$ & $\%$ & $\mathrm{n}$ & $\%$ \\
\hline Patient is alive & 29 & 78.4 & 19 & 90.5 \\
\hline Death & 8 & 21.6 & 2 & 9.5 \\
\hline
\end{tabular}

Outcome of the total patients at four-week follow-up according to their CT scan findings (n=100):

During four-week follow-up it was observed that 29(43.3\%) hemorrhage and 19(57.6\%) infarct patients were alive. The results are shown in the table 13.

Table13: Outcome of the total patients at four-week follow-up according to their CT scan findings $(\mathrm{n}=100)$

\begin{tabular}{|l|l|l|l|l|}
\hline At four week & \multicolumn{3}{|l|}{$\begin{array}{l}\text { Hemorrhage } \\
(\mathrm{n}=67)\end{array}$} & $\begin{array}{l}\text { Infarct } \\
(\mathrm{n}=33)\end{array}$ \\
\hline & $\mathrm{n}$ & $\%$ & $\mathrm{n}$ & $\%$ \\
\hline Patient is alive & 29 & 43.3 & 19 & 57.6 \\
\hline Death & 38 & 56.7 & 14 & 42.4 \\
\hline
\end{tabular}




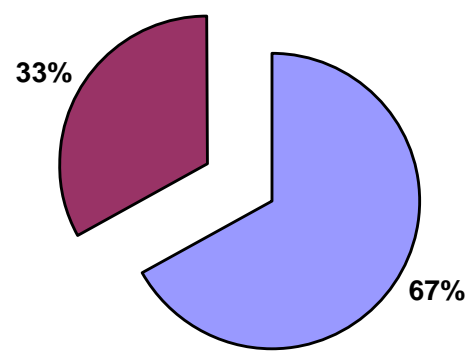

\section{$\square$ Hemorrhage $\square$ Infarct}

Figure 2 shows percentage of patients of hemorrhage and infarction.

\section{Discussion}

In this study, the age ranged between 38 to 80 years. Mean age was between 51-60 years (39\%), and patients with age 61-70 years were 29\%. (Sarker et al, 1993) found 37.5\% patients in the sixth decade, 30\% in the seventh decade with an age range of 25-84 years. ${ }^{[6]}$ So, in this study relatively in earlier age patient developed stroke, $68 \%$ in 5 th $\&$ 6th decades of age which differs from Sarker et al (1993). Increasing age (age $>67$ years) is it self a risk factor for stroke. In Bangladesh, where average life expectancy is 57 years, age more than 55 years may be considered as increasing age.

The male to female ratio was $1.56: 1$ i.e. $61.0 \%$ were male and rest $39.0 \%$ female patients. The disproportionate male preponderance may be due to increase risk of stroke in male sex. More over it may be due to decreased allocation of female bed in our hospital and attitude of our society that female were not brought to the hospital for treatment. This finding is similar with that of Hayee et al (1998) where 57.2\% were male and rest $42.8 \%$ were female. ${ }^{[7]}$ But this result differs with the study of (Miah et al, 2009) where $70.49 \%$ were male and $29.51 \%$ were female. ${ }^{[8]}$ Hypertension is major risk factor for intracerebral hemorrhage in general, it is commonly considered to be associated with deep hemorrhage. In present study $70 \%$ of patients had hypertension, which was the commonest risk factor of stroke. This finding is almost similar with that of (Arif et al, 2003), where they have shown, $67 \%$ were hypertensive. ${ }^{[9]}$ In present study, on the basis of GCS scale, in group I (severe group) systolic blood pressure was $174.9 \pm 53.5$ and varied from 100-280 mm of $\mathrm{Hg}$.

With the above findings, I found, in-group I, both high SBP and DBP were present. More over patients with hypotension (both SBP and DBP) were present in the group I. In case of DBP results were statistically significant $(\mathrm{P}<0.05)$ in three groups. So both high blood pressure and low blood pressure (hypotension) predict the poor outcome of stroke. Acute ischaemic or haemorrhagic stroke patients with high and low admission BP values have a higher early and late mortality which is near about similar with Vemmo et al-(2004). But these findings are not similar with the study of Chao et al (2009) where only systolic blood pressure were significantly higher among non surviving patients. ${ }^{[10]}$ In this study, $14 \%$ patients had history of diabetes mellitus. This finding was nearer the findings of (Braga et al,2002), they found $15 \%$ of the patient with DM. ${ }^{[11]}$

In present study, high blood sugar more in group I (more severe group) which was similar with the findings of Weir et al (1997) in which high blood sugar is directly associated with high mortality, even after adjusting for other prognostic variables. In the previous study (Hamidon and Raymond, 2003), mortality was significantly related to a high level of blood glucose at admission. ${ }^{[12]}$ In contrary, Bhatia et al (2004) did not found significantly relation in between high level of blood glucose and mortality of acute stroke. ${ }^{[13]}$

Cigarette smoking increases the risk of stroke about 2-3 folds (Biller et al, 2008). In this study, 40\% patients have history of smoking. Most of them were male, due to our social custom only small percentage of smokers were female. This finding is nearer with the study of (Braga et al, 2002) where smokers were about $35 \%$.In this study family history of stroke was found in $21 \%$ of patients, which was lower than the study of (Hayee et al,1998), where family history was found in $26.06 \%$. Only $17 \%$ of patients were suffering from heart disease in our study. But in the study of Braga et al (2002), heart diseases were present in $25 \%$ of patients. This discrepancy was probably due to high incidence of cardiovascular disease in developed countries. In this study, it was observed in CT scan finding that $67 \%$ patients had hemorrhagic (ICH) and $33 \%$ patients had ischemic stroke. This result differs with western study where cerebral infarction was $85 \%$, intracerebral hemorrhage $10 \%$ and subarachnoid hemorrhage $5 \%$ of cases. ${ }^{[14]}$ In the study of (Bhalla et al, 2002), 40.5\% patients had intracerebral hemorrhage and $59.5 \%$ patient had infarction. ${ }^{[15]}$

Patients reporting to the hospital in central India are more likely to have hemorrhagic stroke compared to the western patients. ${ }^{[16]}$ This is also true for Bangladesh. This was a hospital-based study. This shows the incidence of intra cerebral hemorrhage is higher in this study, which might be due to the clinical picture of cerebral infarction, is less devastating than intracerebral hemorrhage, which causes decrease frequency of hospitalization among cerebral infarction patients. The total mortality observed in this study group at one week 
was $42 \%$. The patients with hemorrhage having higher mortality of $44.8 \%$ and those with infarction having a lower mortality of $36.4 \%$.

\section{Conclusion}

Predicting outcome in stroke patients is difficult due to the variability in etiology presentation and underling pathophysiology. Total GCS scoring system was found to be statistically significant $(\mathrm{P}<0.05)$ of outcome in critically ill patients having stroke. GCS is a simple method, easy to use and can be applied in those clinical settings where physicians may not have access to sophisticated technology such as MR DWI, used recently (Baird et al, 2001) to predict mortality after stroke. Our study has shown that the total GCS is a valuable tool for prediction of short-term mortality in acute stroke patients in our clinical settings. Though admission level GCS is a independent predictor of mortality of acute stroke, severity of acute stroke depends upon other various factors like size and site of hemorrhage and infarct, patient's age, co morbidity, etc. So, it would thus be preferable to combine GCS data in a model with other stroke prognostic factors if they were to be used in patient management.

\section{References}

[1]. Allen CMC, Lueck CJ, Dennis M. Neurological disease. In: Boon NA, Colledge NR, Walker BR, Hunter JAA (eds). Davidson's Principles \& Practice of Medicine. 20th ed. Churchill Livingstone, Elsevier 2006; 1145-1256.

[2]. Ropper AH, Brown RH. Adams and Victor's Principles of Neurology. 8th ed. McGraw-Hill companies 2005; 660-740.

[3]. Warlow C. Stroke, Transient ischaemic attack and intracerebral venous thrombosis. In: Donaghy M (ed). Brain's disease of the Nervous system. 11th edi. Oxford 2002; 776-856.

[4]. World Health Organization [WHO]. Geneva: WHO; 2004. World health report 2004: Changing history [online]. Accessed on April 24, 2007.

[5]. World Health Organization [WHO]. Report of the WHO Task Force on Stroke and other Cerebrovascular Disorders. Recommendations on stroke prevention, diagnosis and therapy. Stroke 1989; 20:1407-10.

[6]. Sarker CB, Islam MR, Das AB et al. Risk factors for stroke: A study of eighty cases in two district hospitals in Bangladesh. Bangladesh Journal of Neuroscience 1993; 9 (2): 48-55.

[7]. Hayee MA, Haque A, Anwarullah AKM et al. Analysis of risk factors of stroke in 472 cases. Bangladesh Journal of Neuroscience 1998; 14 (2): 41-54.

[8]. Miah M T, Hoque AA, Khan RR et al. The Glasgow Coma Scale following acute stroke and in-hospital outcome: an observational study. J Medicine, 2009; 10(Supplement 1): 11-14.

[9]. Arif SM, Khan MA, Khan N, Mohammad QD. Relation of Hypertension with stroke-A study of 100 cases. Bangladesh Journal of Neuroscience, 2003; 19(2): 59-64.

[10]. Chao CC, Wang TL, Chong CF et al. Prognostic value of QT parameters in patients with acute hemorrhagic stroke: A prospective evaluation with respect to mortality and post-hospitalization bed confinement. J Chin Med Assoc, 2009; 72 (3): 124-132.

[11]. Braga P, Ibarra A, Rega I et al. Prediction of early mortality after acute stroke. Journal of stroke and Cerebrovascular Diseases, 2002;11:15-22.

[12]. Hamidon BB, Raymond AA. The impact of Diabetes Mellitus on In-hospital Stroke Mortality. JPMG 2003 ; 49 (4): $307-310$.

[13]. Bhatia RS, Garg RK, Gaur SPS et al. Predictive value of routine hematological and biochemical parameters on 30-day fatality in acute stroke. Neurology India 2004; 52: 220-223.

[14]. Smith WS, Johnston SC, Easton JD. Cerebrovascular disease. In: Kasper DL, Braunwald E, Fauci AS et al (eds). Harrison's principles of internal medicine. 16th ed. New Delhi: McGraw-Hill, Medical Publishing Division 2005; $2372-93$.

[15]. Bhalla A, Gupta OP, Gupta SB. Predicting mortality in stroke. Neurol India 2002;50:279-283.

[16]. Badam P, Solao V, Pai M et al. Poor accuracy of the Siriraj and Guy's hospital stroke scores in distinguishing hemorrhagic from ischemic stroke in a rural, tertiary care hospital. Natl Med J India, 2003;16:8-12.

[17]. Baird AE, Dambrosia J, Janket S, et al. A three-item scale for the early prediction of stroke recovery. Lancet, 2001; 357:2095-99. 